\title{
ANALIZA STRATEŠKEGA KONCEPTA NATA 2010
}

Povzetek Nato je v času svojega obstoja sprejel sedem strateških konceptov. Okoliščine, v katerih so bili sprejeti, so bile zelo različne, pri čemer si vsi delijo enak namen, to je definiranje temeljnih nalog in usmerjanje delovanja zavezništva. Nato je po hladni vojni iskal novo težišče delovanja, s čimer je začel spreminjati svoj značaj. Sprva obrambna organizacija, namenjena izvajanju kolektivne obrambe, je začela širiti obseg nalog, območje delovanja in postopoma prevzemala nove varnostne naloge.

Odločitev za izdelavo novega strateškega koncepta je bila sprejeta zlasti zaradi obsežnih sprememb v mednarodnem varnostnem okolju, novih varnostnih tveganj in oblik odzivanja nanje. Koncept je bil sprejet novembra 2010 v Lizboni. Zastavljen je bil zelo ambiciozno, saj prinaša več bistvenih sprememb, med katerimi izstopata izenačitev pomena kriznega upravljanja in kooperativne varnosti z zagotavljanjem kolektivne obrambe ter širitev interpretacije 5. člena Washingtonske pogodbe. Koncept krepi pomen celostnega pristopa pri izvajanju kriznega upravljanja ter sodelovanja zavezništva z drugimi mednarodnimi organizacijami, določa razvoj novih zmogljivosti, širi geografsko območje svojega delovanja ter nalaga nadaljnje preoblikovanje organizacije.

Mednarodna varnost, Nato, strateški koncept.

besede

Abstract NATO has so far adopted seven strategic concepts. The circumstances in which they were adopted differentiated substantially, but they all share the same goal which is to define the core tasks and route the wok of the Alliance. After the Cold War, NATO sought a new focus of its activity by which it began changing its character. What was initially a defense organization, dedicated to the implementation of collective defense, began to expand the scope of its tasks, operating range and gradually assuming new security missions. 
The decision to create the new Strategic Concept was adopted mainly because of major changes in the international security environment, new security risks and forms of response. The new strategic concept was adopted in November 2010 in Lisbon and has been designed in a very ambitious manner. It includes several significant changes, two of the most striking ones being the equalization of importance of crisis management and cooperative security by providing collective defense, and wider interpretation of Article 5 of the Washington Treaty. The concept reinforces the importance of a comprehensive approach in the implementation of crisis management and cooperation of the Alliance with other international organizations. It requires the development of new capabilities within NATO; expands its geographical area of operations, and requires further transformation of the organization.

\section{Keywords International security, NATO, Strategic Concept.}

Uvod Po hladni vojni se je bistveno spremenil značaj varnostne paradigme, ki vključuje izzive, probleme, ogrožanja varnosti, odzive nanje, procese in institucije (Grizold, 2005). Radikalno so se spremenili strateški dejavniki, ki določajo varnost posamezne države in mednarodne skupnosti. Ti dejavniki so geopolitični, geostrateški, geoekonomski, znanstvenotehnološki, varnostni, ekološki in drugi (Grizold in Čehulič, 2006).

Mednarodno varnostno okolje je postalo nepredvidljivo in negotovo. Zanj je značilna večplastnost ogrožanja varnosti, ki obsega štiri bistvene elemente (Grizold, 2005). Prvič, povezovanje, prepletanje in medsebojno delovanje vojaških ter nevojaških groženj varnosti, kot so vojaški in etnični konflikti, širjenje orožja za množično uničevanje, organizirani kriminal, terorizem, naravne in druge nesreče, lakota, nalezljive bolezni, onesnaževanje okolja itn. Drugič, preoblikovanje nacionalne varnosti v mednarodno varnost in obratno. Varnostna problematika je pridobila globalne razsežnosti v prostorskem smislu (vključuje posameznika, družbene skupine, države in mednarodno skupnost v celoti) ter v vsebinskem smislu, pri čemer obsega vse vidike človekovega obstoja in delovanja v družbi, kot so gospodarski, družbeni, politični, izobraževalni, komunikacijsko-informacijski, obrambni itn., ter vse ravni družbenega povezovanja. V tem okviru je postala varnost posamezne države vse bolj domena tudi globalnega mednarodnega sistema. Tretjič, močno sta se okrepili povezanost in odgovornost med subjekti zagotavljanja varnosti, med katere spadajo države, meddržavne in naddržavne organizacije, nevladne organizacije, večnacionalne korporacije, skupine pritiska in druge (Roper in Crockart v Grizold, 2005). Četrtič, instrumenti in mehanizmi za zagotavljanje varnosti so postali bistveno bolj zapleteni ter se povezujejo $\mathrm{v}$ sistem tako na ravni države (na primer nacionalnovarnostni sistem) kot na ravni mednarodne skupnosti (OZN, sodelovanje držav v operacijah kriznega odzivanja idr.).

Z razpadom Sovjetske zveze in Varšavskega sporazuma ni bilo več glavnega vira ogrožanja Nata. Kljub temu je zavezništvo še naprej ostalo pomembna organizacija 
za države članice na obeh straneh Atlantika (Helbig, 2011). Zavezništvo se je po razpadu bipolarnosti zelo spremenilo, kar je posledica njegovega prilagajanja novim varnostnim razmeram. Za zadnje desetletje delovanja Nata je značilno, da so se države članice soočile $z$ neenotnostjo svojih pogledov glede odgovornosti zavezništva za varnost sveta po terorističnem napadu na ZDA, večina evropskih držav je zaradi ekonomske recesije znatno zmanjšala svoje obrambne proračune, administracija ZDA s predsednikom Georgeem Bushem na čelu pa je začela izvajati enostranske operacije in tako spodkopala čezatlantsko partnerstvo. Ne glede na to so se ZDA, Kanada ter evropske države aprila 2009 v Strasbourgu in Kehlu dogovorile za pripravo nove skupne strategije delovanja zavezništva, ki je novembra 2010 nasledila Strateški koncept Nata iz leta 1999 (Helbig, 2011).

Strateški koncept Nata je po hierarhiji drugi najvišji akt, takoj za Washingtonsko pogodbo iz leta 1949, in daje usmeritve za delovanje zavezništva v srednjeročnem obdobju. Strateški koncept Nata 2010 je tretji strateški koncept zavezništva po hladni vojni in je eden ključnih aktov, ki opredeljuje delovanje ne le zavezništva, temveč tudi Slovenske vojske, saj je Slovenija kot članica Nata obvezana k izvajanju njegovih določil. Novi koncept je zastavljen zelo ambiciozno; določa širok spekter tveganj in nalaga Natu izvajanje široke palete nalog, tako vojaških kot nevojaških.

Ob proučevanju novega strateškega koncepta se postavlja več vprašanj: ali bo zavezništvo lahko doseglo cilje, ki jih določa strateški koncept; kje se lahko pojavijo težave in zakaj; ali si je Nato morda postavil preveč nalog; ali bodo države članice sposobne preseči svoje različne poglede na varnostna vprašanja; ali bodo države pokazale politično voljo za uresničevanje vseh nalog iz koncepta; ali koncept določa prednostne naloge pri izvajanju Natovih nalog; ali koncept geografsko določa okvire Natovega delovanja; ali strateški koncept preobraža zavezništvo iz obrambnega zavezništva v varnostno organizacijo; kako se bo zavezništvo razvijalo v prihodnje. Na nekatera izmed teh vprašanj bom poskušal odgovoriti v nadaljevanju, medtem ko bodo druga ostala odprta za nadaljnja proučevanja.

V prispevku bodo osvetljeni vzroki in dejavniki, ki so privedli do strateškega koncepta Nata 2010, njegove novosti, analizirano bo razmerje med obrambnimi in varnostnimi prvinami koncepta ter dane dileme in kritični pogledi nanj. $\mathrm{V}$ ta namen bosta uporabljeni metodi analiza pisnih virov in primerjalna metoda.

\section{OPREDELITEV STRATEŠKEGA KONCEPTA}

Pri pregledu literature naletimo na več poskusov definicij strateškega koncepta. Alcaro ga opredeli kot akt, ki periodično ažurira ter interpretira poslanstva, vlogo in naloge zavezništva ter opravlja dve temeljni funkciji, prvič, podajanje strateških usmeritev za delovanje zavezništva $\mathrm{v}$ srednjeročnem obdobju, in drugič, krepitev javne podpore Natu, in sicer s predstavitvijo vzrokov, zakaj je ta, ne glede na obveznosti, ki jih nalaga svojim članicam, zanje še vedno pomembna in potrebna organizacija (Alcaro, 2010). Flockhart ugotavlja, da strateški koncept Nata odraža 
spremembe, bodisi v zunanjem varnostnem okolju bodisi znotraj organizacije. Po njegovem izkazuje strateški koncept operativno videnje Washingtonske pogodbe, ki določa ključne vrednote Nata ter pravice in obveznosti držav članic. Oba dokumenta skupaj opredeljujeta, kaj je Nato in kaj bi moral početi. Ključna funkcija strateškega koncepta je torej definiranje vloge ter nalog Nata $\mathrm{v}$ aktualnem varnostnem okolju, vendar vedno skladno z vrednotami, navedenimi v Washingtonski pogodbi (Flockhart, 2011). Podobno kot Flockhart tudi Ringsmose razume strateški koncept kot operativen pogled Nata na Washingtonsko pogodbo. Ta ne določa groženj, tveganj ali geografskega območja interesa zavezništva. S strateškim konceptom Nato ponovno interpretira Washingtonsko pogodbo in usklajuje svoje interese ter strateške poglede $\mathrm{z}$ varnostnim okoljem. Ključno področje, ki ga mora strateški koncept opredeliti, je določitev tveganj in njihovih vojaških posledic. Po njegovem mnenju opravljajo sodobni strateški koncepti tri temelje funkcije: dve notranji in eno zunanjo. Med notranje spadata utrjevanje temeljev zavezništva in dajanje strateških usmeritev, s katerimi se postavljajo temelji prihodnjega skupnega delovanja, zunanja funkcija strateških konceptov pa je izvajanje javne diplomacije, s katero Nato predstavlja svoje aktivnosti varnostni skupnosti ter poskuša za to pri svojih članicah pridobiti čim večjo podporo (Ringsmose in Rynning, 2009).

Na podlagi pregleda definicij razberemo glavne značilnosti strateških konceptov Nata:

- po hierarhiji dokumentov se strateški koncepti uvrščajo takoj za Washingtonsko pogodbo;

- zunanja in notranja determiniranost, pri čemer se prva izraža v spremenjenih varnostnih razmerah, grožnjah, tveganjih ipd., druga pa v interesih in potrebah držav članic organizacije;

- temeljne funkcije so utrjevanje zavezništva, usmerjanje delovanja, vojaški in politični razvoj organizacije, preoblikovanje oziroma prilagajanje vojaških zmogljivosti in javna diplomacija (to velja za novejše strateške koncepte);

- cilj je ponovna določitev vloge in nalog zavezništva;

- časovno omejena veljava.

\section{RELEVANTNOST STRATEŠKEGA KONCEPTA NATA 2010}

Spremembe v varnostnem okolju, ki smo jim bili priča kmalu po prehodu v novo tisočletje, so obudile razmišljanja o potrebi po prenovi Natovega strateškega koncepta. V strokovni in politični javnosti sprva ni bilo enotnega mnenja o tem, ali zavezništvo potrebuje nov strateški koncept. Oblikovala sta se dva bloka, prvi je zagovarjal potrebo po njegovem sprejemu, drugi pa je tej ideji nasprotoval. Zagovorniki novega strateškega koncepta so navajali več argumentov za njegovo ponovno definiranje (Kugler in Binnendijk, 2008):

- varnostno okolje in tveganja so se od sprejetja prejšnjega strateškega koncepta toliko spremenili, da ta ni več podajal ustreznih usmeritev za delovanje zavezništva;

- Nato naj ne bi imel ustrezne vizije, izvajal je vrsto aktivnosti, ki so presegale okvir takratnega strateškega koncepta, pred njim naj bi bile nove naloge in vse to bi 
bilo treba povezati v koherentno celoto, za kar bi bil najustreznejši novi strateški koncept;

- Nato naj bi bil deležen nizke podpore javnega mnenja na obeh straneh Atlantika, kar odraža pomanjkljivo izvajanje skupne varnostne politike. Novi strateški koncept naj bi pomagal povrniti ugled in podporo javnosti zavezništvu;

- izdelati naj bi bilo treba nov koncept, ki bo zavezništvu dal tisto, kar se od njega pričakuje, to je posredovanje strateških usmeritev za opravljanje nalog v mednarodnem okolju, ki ga zaznamujejo velike spremembe, kompleksnost ter številne nevarnosti;

- novi strateški koncept naj bi Natu pomagal izboljšati učinkovitost delovanja zlasti s tem, da bi mu omogočil razvoj novih zmogljivosti in rešitev za uspešno opravljanje novih nalog;

- kljub političnim nesoglasjem, ki jih je povzročil napad na Irak leta 2003, med ZDA in Veliko Britanijo na eni strani ter Francijo in Nemčijo na drugi, naj bi se odnosi med njimi že toliko normalizirali, da bi bilo sodelovanje pri snovanju novega strateškega koncepta mogoče.

Nasprotniki izdelave novega strateškega koncepta so svoje stališče podkrepili z argumenti (Kugler in Binnendijk, 2008; Flockhart, 2011; Wittmann, 2009):

- snovanje novega strateškega koncepta naj bi razkrilo številna politična nesoglasja med državami, kar naj bi onemogočalo izdelavo kakovostnega dokumenta;

- poskus izdelave novega koncepta naj bi privedel do tolikšne politične razdrobljenosti med državami, da bi to oslabilo Natovo kohezijo in sposobnost skupnega in enotnega delovanja;

- novi strateški koncept ni potreben, saj naj bi bil veljavni, dopolnjen s sklepi zasedanj Natovih vrhov in drugimi ustreznimi akti, povsem zadovoljiv ter se lahko še vedno uporablja za usmerjanje delovanja in načrtovanje aktivnosti Nata;

- Nato naj bi v zadnjih letih izkazoval zmožnost vzpostavitve novih zmogljivosti in izvajanja novih nalog, ne da bi bilo za to treba prenoviti strateški koncept;

- Nato lahko učinkoviteje okrepi svoje delovanje z uresničitvijo praktičnih korakov kot pa z razpravljanjem o svojih strateških teorijah;

- čas za pisanje nove strategije naj ne bi bil primeren zaradi iztekanja mandata Busheve administracije, pri čemer naj bi nova administracija potrebovala vsaj eno leto za določanje svojih strateških prednostnih nalog;

- strateški dokumenti niso usmerjeni v prihodnost, temveč le povzemajo, o čemer so se že dogovorili v zavezništvu.

Obveljalo je prepričanje, da je treba strateški koncept zavezništva iz leta 1999 posodobiti. Organizacija je tako leta 2009 sprejela Deklaracijo o varnosti zavezništva, ki jo lahko označimo za neke vrste predhodnika novega koncepta Nata (Ringsmouse in Rynning 2011, str. 12-13). Ta vsebuje splošne politične usmeritve za delovanje Nata do sprejetja novega koncepta in med drugim daje usmeritve za njegovo pripravo. Generalni sekretar Nata je na njeni podlagi imenoval skupino 12 strokovnjakov, ki jih je vodila nekdanja zunanja ministrica ZDA, Madeleine Albright. Ta je pripravila poročilo Nato 2020: zagotovljena varnost, dinamično delovanje, ki je odražalo 
njihov pogled na temeljne elemente delovanja Nata $\mathrm{v}$ prihodnosti in je bilo uporabljeno kot izhodišče za pripravo novega strateškega koncepta, katerega besedilo se je nato usklajevalo vse do njegovega sprejetja novembra 2010.

\section{NAJPOMEMBNEJŠE NOVOSTI}

Novi strateški koncept je na prvi pogled zelo podoben prej veljavnemu in vsebuje vrsto aktivnosti, ki jih je Nato že izvajal v preteklosti. Temeljne naloge zavezništva ostajajo podobne. Ena glavnih nalog je izvajanje kolektivne obrambe na podlagi 5. člena Washingtonske pogodbe, ki temelji na odvračanju s konvencionalnimi in jedrskimi silami. Koncept vidi Nato kot jedrsko zavezništvo, pri čemer bo organizacija najverjetneje vztrajala vse dotlej, dokler to orožje ne bo popolnoma ukinjeno. Koncept poudarja pomen solidarnosti med članicami, transatlantske povezave, posvetovanj med članicami o vseh pomembnih vprašanjih o njihovi varnosti in pomen odnosov med Natom in OZN. Strateški koncept ponovno izpostavlja pomen temeljnih vrednot in načel Nata ter povzema celo vrsto aktivnosti, ki jih je Nato že počel v preteklosti. Sem spadajo področje nadzora nad oboroževanjem, na katerem je Nato večkrat služil kot forum za posvetovanje med zavezniki, ter področje transatlantskega posvetovanja in njegova politična vloga, prek katere so potekali pogovori o vseh mednarodnih varnostnih krizah. Podobno kot prejšnji koncept tudi novi poudarja pomen kriznega upravljanja in stabilizacijskega delovanja zunaj meja držav članic. Pri tem izpostavlja nujnost okrepljenega sodelovanja z drugimi akterji v mednarodni skupnosti. Koncept kot eno bistvenih aktivnosti Nata izpostavlja partnerstvo in politiko odprtih vrat (Shea, 2011).

Katere so glavne novosti v strateškem konceptu 2010? Koncept navaja tri temeljne naloge zavezništva: kolektivno obrambo, krizno upravljanje in kooperativno zagotavljanje mednarodne varnosti. Delitev temeljnih nalog Nata na tri kategorije se zdi na prvi pogled nepomembna, vendar je $\mathrm{v}$ resnici bistvena za določanje novega značaja zavezništva. Skladno z novo klasifikacijo nalog so za Nato vse tri enako pomembne, kar pomeni velik odmik od prejšnjega koncepta. Strateški koncept iz leta 1999 je določal temeljne in drugotne naloge. Med prve je uvrstil varnost, posvetovanje ter odvračanje in obrambo, med druge pa krizno upravljanje in partnerstvo (Natov strateški koncept 1999, 10. člen). Tako se novi koncept približuje zagovornikom globalizma (zlasti ZDA), ki zagovarjajo Nato kot zavezništvo, ki se bo sposobno spoprijeti z varnostnimi tveganji, kjer koli in kadar koli se bodo pojavila, kar pomeni velik korak pri preoblikovanju Nata v smeri ekspedicijskega zavezništva.

Teritorialna usmerjenost Nata se je z novim strateškim konceptom zmanjšala na najmanjšo možno mero in jo zasledimo le še $\mathrm{v}$ povezavi s protiraketno obrambo ozemlja organizacije ter v zvezi z zagotavljanjem transatlantskega foruma za posvetovanje o vseh temah, ki zadevajo teritorialno integriteto, politično neodvisnost in varnost članic (Flockhart, 2011). Temu lahko dodamo še odgovornost Nata za zaščito in obrambo ozemlja pred napadom. Zmanjšanje teritorialne usmerjenosti Nata odraža dejstvo, da je značaj novih varnostnih tveganj takšen, da ta večinoma ne ogrožajo ozemlja držav, kar velja za konvencionalne grožnje, temveč njihovo varnost. 
Novi strateški koncept poudarja v delu, ki opredeljuje izvajanje kolektivne obrambe, da bo Nato odvrnil in branil članice pred vsako grožnjo agresije, kar je bilo zapisano tudi v strateških konceptih iz let 1991 in 1999. Ena bistvenih novosti novega koncepta je, da predvideva zagotavljanje kolektivne obrambe tudi proti varnostnim tveganjem, kadar ta ogrožajo varnost posameznih držav ali Nata kot celote. Vendar pa Nato ne bo izvajal obrambe članic pred vsemi tovrstnimi tveganji, temveč se bo o tem odločal od primera do primera. Izvajanje kolektivne obrambe se torej nanaša na celotno paleto varnostnih tveganj, ki jih novi koncept navaja v poglavju varnostno okolje. Mednje spadajo poleg konvencionalnih groženj, ki še niso v celoti odpravljene, tudi nekonvencionalna tveganja: jedrsko orožje, širjenje jedrskega in drugega orožja za množično uničenje ter sredstev za njihov prenos, balistične rakete, terorizem, nestabilnost, preprodaja orožja, ljudi in drog, kibernetski napadi ter grožnje vitalnim komunikacijam, transportu in tranzitnim potem, ki pa se jim ne da upreti le z vojaškimi sredstvi. V zvezi z novimi tveganji se postavlja vprašanje, kako se bo Nato spoprijel s podnebnimi spremembami kot dejavnikom tveganja, ki ga navaja novi strateški koncept (Ringsmose in Rynning, 2011).

Novi koncept s svojo vsebino zadovolji tako zagovornike jedrskega odvračanja kot jedrske razorožitve. Nato si bo prizadeval za vzpostavitev sveta brez jedrskega orožja, v nadaljevanju pa koncept navaja, da bo zavezništvo uporabilo jedrsko orožje le v izjemnih okoliščinah in da bo Nato ostal jedrsko zavezništvo, vse dokler bo to orožje obstajalo. Koncept nalaga organizaciji razvoj protiraketne obrambe, pri čemer si bo ta prizadevala za sodelovanje z Rusijo in drugimi evroatlantskimi partnerji (Ringsmose in Rynning, 2011; Natov strateški koncept 2010, 17.-18. člen).

$\mathrm{Na}$ podlagi izkušenj, pridobljenih v Afganistanu in na Zahodnem Balkanu, daje koncept usmeritve, namenjene krepitvi prispevka Nata k celostnemu političnemu, civilnemu in vojaškemu pristopu. Nato mora aktivno sodelovati z drugimi mednarodnimi akterji, da bi okrepil učinkovitost izvajanja nalog. Zavezništvo naj bi v ta namen okrepilo zmogljivosti za opazovanje in analiziranje mednarodnega okolja, kar mu bo omogočilo odkrivanje potencialnih novih kriznih žarišč ter reševanje kriz, še preden prerastejo v konflikt; vzpostavilo ustrezne civilne zmogljivosti za krizno upravljanje, kar mu bo omogočalo učinkovitejše sodelovanje s civilnimi partnerji; razvilo zmogljivosti za izvajanje urjenja in razvoja lokalnih sil na območjih delovanja, s čimer bi omogočilo čimprejšnji prenos odgovornosti za zagotavljanje svoje varnosti; usposobilo ustrezne civilne strokovnjake, ki bi bili na voljo za takojšnje delovanje, ter okrepilo politična posvetovanja v vseh fazah krize. Koncept pri tem ne navaja geografskih omejitev delovanja. Vsi navedeni ukrepi so namenjeni krepitvi sposobnosti operativnega delovanja Nata ter bodo zagotavljali zavezništvu status pomembnega partnerja za vsako varnostno organizacijo (Natov strateški koncept 2010, 16.-19. člen; Ringsmose in Rynning, 2011).

Na področju krepitve mednarodne varnosti s sodelovanjem izstopa zelo ambiciozen cilj, ustvariti pogoje za svet brez jedrskega orožja (Natov strateški koncept 2010, Uvod). Gre za nadaljevanje politike koncepta iz leta 1999, kar med drugim pomeni 
nadaljevanje jedrskega razoroževanja v Natu. Zavezništvo se zavzema za krepitev partnerstva z Rusijo, OZN, Evropsko unijo in drugimi. Nato še naprej ostaja odprt za sprejem novih evropskih držav, ki bodo dosegale zahtevane standarde (Natov strateški koncept 2010, str. 26-35; Ringsmose in Rynning, 2011).

$\mathrm{V}$ poglavju Reforma in transformacija je opisan koncept usmeritve za nadaljnji razvoj organizacije, ki naj bi ji omogočil uresničitev vseh zadanih nalog. Nato mora imeti zato na voljo dovolj človeških, materialnih in finančnih virov, ki morajo biti učinkovito uporabljeni. Okrepiti mora razmestljivost sil, zagotoviti skladno načrtovanje, preprečiti podvajanje in se usmeriti v modernizacijo, skupno razvijati ter uporabljati zmogljivosti, krepiti skupne zmogljivosti in nadaljevati reforme struktur (Natov strateški koncept 2010, 36.-37. člen). Ne glede na finančno krizo, s katero se danes srečuje večina držav članic, koncept zavezništvu nalaga, da ostaja zvesto reformam, ki bodo omogočile, da bodo davkoplačevalci za svoj denar dobili največ varnosti. V primerjavi z novim konceptom prejšnji v ničemer ni neposredno navajal davkoplačevalcev (Ringsmose in Rynning, 2011).

Za učinkovito spoprijemanje $\mathrm{z}$ novimi tveganji predvideva novi strateški koncept razvoj zmogljivosti, s katerimi se bo zavezništvo lahko upiralo kibernetskim napadom in grožnjam kritični infrastrukturi, okrepilo zmogljivosti za detekcijo terorizma in obrambo proti njemu ter zmogljivosti, ki mu bodo omogočile izvajanje celotnega spektra kriznega upravljanja. Za uspešno obvladovanje široke palete nalog in tveganj, ne glede na njihovo lokacijo, bo Nato razvil vojaške zmogljivosti za ekspedicijsko delovanje ter oblikoval omejene civilne zmogljivosti za izvajanje kriznega upravljanja, kar je v okolju, ki ga zaznamujejo gospodarske težave in fiskalne omejitve, zelo ambiciozen načrt.

\section{RAZMERJE MED OBRAMBNIMII IN VARNOSTNIMII PRVINAMI}

Razmerje med obrambnimi in varnostnimi prvinami strateškega koncepta omogoča razumevanje narave zavezništva. Za koncepte, ki so bili sprejeti v času hladne vojne, je veljalo, da so v njih prevladovale obrambne prvine. Temeljna naloga zavezništva sta bila odvračanje in kolektivna obramba članic, pri čemer se je Nato opiral zlasti na obsežne in robustne oborožene sile. Po hladni vojni se je narava organizacije začela spreminjati, saj je začela širiti obseg nalog in spreminjati svoje zmogljivosti. Razmejitev med obrambnimi in varnostnimi prvinami strateškega koncepta ter posledično zavezništva temelji na analizi Natovega strateškega koncepta iz leta 2010. Posamezne prvine so razvrščene v eno izmed štirih področij (grožnje/tveganja, območje delovanja, naloge in zmogljivosti) ter glede na svojo naravo umeščene bodisi v obrambno bodisi v varnostno področje (glej tabelo 1). 


\begin{tabular}{|c|c|c|c|}
\hline \multirow{8}{*}{$\begin{array}{r}\text { Tabela 1: } \\
\text { Razmerje med } \\
\text { obrambnimi } \\
\text { in varnostnimi } \\
\text { prvinami } \\
\text { Strateškega } \\
\text { koncepta Nata } \\
2010\end{array}$} & PODROČJE & OBRAMBNE PRVINE & VARNOSTNE PRVINE \\
\hline & 1. Grožnje in tveganja & $\begin{array}{l}\text { Konvencionalni napad ter napad } \\
\text { z jedrskim, biološkim in kemičnim } \\
\text { orožjem; širjenje orožja za množično } \\
\text { uničenje in sredstev za njihov prenos. }\end{array}$ & $\begin{array}{l}\text { Terorizem; preprodaja orožja, drog in } \\
\text { ljudi; kibernetski napadi; ogrožanje } \\
\text { vitalnih komunikacij, transportnih in } \\
\text { tranzitnih poti, tveganja energetski } \\
\text { varnosti; okoljska tveganja. }\end{array}$ \\
\hline & \multirow{3}{*}{ 2. Naloge } & \multirow{3}{*}{$\begin{array}{l}\text { Izvajanje kolektivne obrambe: Nato } \\
\text { bo odvrnil in branil pred grožnjo z } \\
\text { napadom. }\end{array}$} & $\begin{array}{l}\text { Izvajanje kolektivne obrambe: Nato bo } \\
\text { odvrnil in varoval pred varnostnimi } \\
\text { tveganji. }\end{array}$ \\
\hline & & & $\begin{array}{l}\text { Krizno upravljanje: Nato bo izvajal } \\
\text { operacije pred nastankom krize, med } \\
\text { krizo ter po krizi, za kar bo uporabil } \\
\text { politične in vojaške zmogljivosti. }\end{array}$ \\
\hline & & & $\begin{array}{l}\text { Kooperativna varnost: prispevati } \\
\text { k mednarodni varnosti v sodelovanju } \\
\text { z drugimi državami in organizacijami. }\end{array}$ \\
\hline & 3. Območje delovanja & Geografska omejitev ni navedena. & Geografska omejitev ni navedena. \\
\hline & \multirow[t]{2}{*}{ 4. Zmogljivosti } & \multirow[t]{2}{*}{$\begin{array}{l}\text { Vojaške zmogljivosti: konvencionalne } \\
\text { vojaške zmogljivosti, jedrske sile, } \\
\text { protiraketna obramba, zmogljivosti za } \\
\text { obrambo pred jedrskimi, kemičnimi in } \\
\text { biološkimi napadi. }\end{array}$} & $\begin{array}{l}\text { Razvoj zmogljivosti za preprečevanje } \\
\text { in delovanje proti kibernetskim } \\
\text { napadom; za zaznavanje ter boj } \\
\text { proti mednarodnemu terorizmu in } \\
\text { za zagotavljanje energetske varnosti, } \\
\text { varnosti kritične infrastrukture ter } \\
\text { tranzitnih poti; razvoj ekspedicijskih } \\
\text { zmogljivosti za izvajanje kriznega } \\
\text { upravljanja; formiranje civilnih } \\
\text { zmogljivosti za izvajanje kriznega } \\
\text { upravljanja; razvoj zmogljivosti za } \\
\text { vzpostavitev, urjenje in razvoj lokalnih } \\
\text { varnostnih struktur. }\end{array}$ \\
\hline & & & $\begin{array}{l}\text { Uporaba celostnega pristopa pri } \\
\text { kriznem upravljanju - sodelovanje } \\
\text { z drugimi mednarodnimi akterji. }\end{array}$ \\
\hline
\end{tabular}

Vir: Strateški koncept Nata 2010

$\mathrm{Na}$ področju groženj in tveganj strateški koncept navaja grožnje zavezništvu s konvencionalnim, jedrskim, biološkim in kemičnim orožjem ter širjenje orožij za množično uničenje in sredstev za njihov prenos, ki jih vse uvrščamo med obrambne prvine koncepta. Na drugi strani ta določa varnostna tveganja: terorizem, preprodajo orožja, drog in ljudi, kibernetske napade, ogrožanje vitalnih komunikacij, transportnih in tranzitnih poti, tveganja za energetsko varnost, okoljska tveganja (Natov strateški koncept 2010, 7.-15. člen), ki jih umeščamo med varnostne prvine. Pregled strateškega koncepta v delu, ki definira grožnje in tveganja za Nato, pokaže, da je delež varnostnih prvin večji kot delež obrambnih. To lahko pojasnimo s spremenjenim varnostnim okoljem, ki prinaša novo percepcijo groženj in tveganj. V ospredje so stopila nevojaška tveganja, ki v preteklosti niso bila tako pomembna, zlasti zaradi prevladujoče grožnje konvencionalnega napada. Naslednji vzrok tiči v potrebi Nata po prilagajanju novim razmeram, kar vključuje tudi ponovno določanje lastnih tveganj in groženj, pri čemer je izhajal iz celostnega pristopa razumevanja varnosti. 
V okviru obrambnih prvin novi strateški koncept določa eno temeljno nalogo Nata, to je odvračanje in obrambo pred grožnjami z napadom, v skladu s 5. členom Washingtonske pogodbe. Med varnostne prvine koncepta uvrščamo preostale temeljne naloge: odvračanje in varovanje pred varnostnimi tveganji, krizno upravljanje in kooperativna varnost (Natov strateški koncept 2010, 4. člen). Obseg temeljnih nalog, ki jih koncept nalaga Natu iz naslova varnostnih prvin, je večji, kot je obseg nalog, ki izhajajo iz njegovih obrambnih prvin. To se kaže tudi v praktičnem delovanju Nata, v katerem danes izstopajo zlasti naloge s področja kriznega upravljanja (Natove operacije na Kosovu, v Afganistanu in v Adenskem zalivu) ter sodelovanje s partnerskimi in drugimi državami ter mednarodnimi organizacijami. Območje delovanja, ki ga določa strateški koncept za izvajanje obrambnih in varnostnih nalog, geografsko ni omejeno. Nato bo opravljal naloge z obeh področij delovanja, kjer koli in kadar koli bo to potrebno za zagotavljanje varnosti zavezništva oziroma za prispevanje k varnosti v mednarodni skupnosti.

Zmogljivosti Nata za opravljanje nalog, ki se uvrščajo v obrambne prvine, obsegajo konvencionalne vojaške zmogljivosti, jedrske sile, protiraketno obrambo v fazi vzpostavljanja ter zmogljivosti za obrambo pred jedrskimi, kemičnimi in biološkimi napadi. Med zmogljivosti, ki se uvrščajo v varnostne prvine, spadajo zmogljivosti za zoperstavljanje kibernetskim napadom, protiteroristične zmogljivosti, zmogljivosti za zagotavljanje energetske varnosti, varnosti kritične infrastrukture in tranzitnih poti, vojaške ekspedicijske zmogljivosti za izvajanje kriznega upravljanja, civilne zmogljivosti za izvajanje kriznega upravljanja ter zmogljivosti za vzpostavitev, urjenje in razvoj lokalnih varnostnih struktur (Natov strateški koncept 2010, 17., 19. in 25. člen). Članice Nata imajo več zmogljivosti za opravljanje nalog, ki jih uvrščamo med obrambne prvine, kot zmogljivosti za opravljanje nalog, ki jih uvrščamo v varnostne prvine. Za opravljanje obrambnih nalog lahko uporabljajo skoraj vse svoje zmogljivosti, nabor zmogljivosti za opravljanje nalog z varnostnega področja pa je omejen. Koncept nalaga zavezništvu razvoj in vzpostavitev novih zmogljivosti, s katerimi bo lahko Nato v prihodnosti v večjem obsegu izvajal tudi naloge s področja varnostnih prvin (zmogljivosti za protikibernetsko, protiteroristično in ekspedicijsko delovanje, okrepitev zmogljivosti za opazovanje in analiziranje mednarodnega okolja, vzpostavitev ustreznih civilnih zmogljivosti za krizno upravljanje, razvoj zmogljivosti za izvajanje urjenja in razvoj lokalnih sil na območjih delovanja idr.).

Spremenjeno varnostno okolje in tveganja so zahtevali oblikovanje novih rešitev za zagotavljanje varnosti. To se zrcali v prestrukturiranju, ki se je v Natu začelo kmalu po koncu hladne vojne in katerega močan pečat je viden tudi v novem strateškem konceptu. Ta odraža skozi razmerje med njegovimi obrambnimi in varnostnimi prvinami novi značaj zavezništva, za katerega je značilna krepitev njegove varnostne dimenzije. 


\section{DILEME IN KRITIKA}

Za obravnavo dilem in kritik, ki se porajajo v novem strateškem konceptu, je bila opravljena analiza najpomembnejših področij delovanja Nata: obramba in odvračanje, krizno upravljanje in kooperativna varnost. Analizirana so bila razmerja med varnostnimi tveganji, ki jih je Nato določil v novem strateškem konceptu, in zmogljivostmi oziroma aktivnostmi za zoperstavljanje proti njim ter naloge in aktivnosti Nata na področju kriznega upravljanja ter kooperativne varnosti.

Obramba in odvračanje. Ugotovimo lahko, da je večina tveganj, ki jih navaja koncept, nevojaškega izvora, zato se tu poraja vprašanje, kako se jim lahko zavezništvo, ki razpolaga pretežno z vojaškimi zmogljivostmi, zoperstavi. Mednje uvrščamo terorizem, nedovoljeno preprodajo orožja, narkotikov in ljudi, kibernetske napade, ogrožanje ključnih komunikacij, transportnih in tranzitnih poti ter okoljska tveganja. Sam se strinjam s Kampom, ki navaja, da ima lahko Nato pri zoperstavljanju nevojaškim tveganjem le podporno vlogo, pri čemer pa mora zavezništvo hkrati delovati kot forum transatlantskega posvetovanja o tovrstnih vprašanjih na podlagi 4. člena Washingtonske pogodbe (Kamp, 2010). Za uspešno reševanje kriz je pomembno enakopravno sodelovanje $\mathrm{z}$ drugimi institucijami in mednarodnimi organizacijami, ki imajo ustrezne zmogljivosti.

Kot izhaja iz strateškega koncepta Nata 2010, se bo zavezništvo zoperstavilo terorizmu z vojaškimi sredstvi. To je na prvi pogled nenavaden in mogoče celo sporen pristop, vendar pa je pri tem treba dodati, da to velja le za tiste oblike terorističnega delovanja, ki znatno ogrožajo varnost posamezne članice ali zavezništva kot celote. $\mathrm{V}$ ta namen bo Nato razvijal zmogljivosti za detekcijo in obrambo pred terorizmom, okrepil analiziranje terorističnih tveganj in posvetovanje s partnerji ter pripomogel k usposabljanju lokalnih varnostnih sil za samostojno protiteroristično delovanje. Poleg navedenega prepoznavam kot eno najpomembnejših Natovih nalog, ki ni navedena v strateškem konceptu, usklajevanje načrtovanja in aktivnosti s civilnimi strukturami, ki delujejo proti terorizmu, česar pa koncept na področju protiterorističnega delovanja ne predvideva.

Nedovoljena preprodaja orožja, narkotikov in ljudi spada med tveganja, ki imajo nevojaški značaj ter so domena civilnih varnostnih struktur (policija, tožilstvo, sodišča, varnostne službe idr.), zato se na tem mestu ponovno postavlja vprašanje, kakšna je pri tem vloga Nata. Strateški koncept pri tem ne daje nikakršnih usmeritev ali pojasnil. Menim, da bi moral koncept jasno razmejiti delovanje Nata v okviru izvajanja nalog odvračanja in varovanja držav članic ali zavezništva pred tovrstnim tveganjem, pri čemer je to predvsem domena policije in pravosodnega sistema. Koncept bi moral pri tem opredeliti sodelovanje in podporo tem inštitucijam. Nadalje bi moral koncept definirati izvajanje teh nalog v okviru operacij kriznega odzivanja, $\mathrm{v}$ katerih se tovrstne naloge izvajajo na podlagi mandata, ki ga podeljuje OZN. 
Kibernetski napadi sodijo med nevojaška tveganja. Zaradi vrste odmevnih napadov, hitrega razvoja virusov in druge škodljive programske opreme so se ti uvrstili med najpomembnejša varnostna vprašanja. Strateški koncept ponuja kot odgovor na ta tveganja nadaljnji razvoj zmogljivosti za preprečevanje, odkrivanje, obrambo in obnovo škode, ki jo ti povzročajo. Gre za splošno usmeritev, ki pa ne zagotavlja uspešnega delovanja, saj bi moral Nato pred tem odgovoriti na več vprašanj, kot so, kaj je kibernetski napad, kdaj se začne in kdaj konča. Ustvarja se vtis, da so kibernetski napadi stalnica, ki spremlja delovanje vitalnih informacijskih sistemov. Nadalje, ali je računalniški virus orožje, ki ga je treba kot takega tudi obravnavati, ali je lahko pri tem odvračanje uspešno, če pa niti ne vemo zagotovo, kdo nas napada, ali je povračilen kibernetski ukrep v današnjih okoliščinah sploh legitimna in učinkovita strategija. Poleg teh se poraja še več drugih vprašanj, ki kažejo na vrsto nedorečenosti in dilem, ki zahtevajo jasne odgovore, saj bo Nato le tako lahko jasno opredelil svojo vlogo ter razvil ustrezne zmogljivosti in aktivnosti na tem področju (Shea, 2011).

Ogrožanje najpomembnejših komunikacij, transportnih in tranzitnih poti lahko uvrstimo med nevojaška ali vojaška tveganja oziroma grožnje. O prvem govorimo, kadar je to posledica dela kriminalnih ali drugih podobnih skupin (na primer piratski napadi v Adenskem zalivu), o drugem pa, kadar so na delu oborožene sile druge države. Strateški koncept odgovarja na tovrstna tveganja z varovanjem kritične energetske infrastrukture, transportnih in tranzitnih poti. Menim, da bi moral strateški koncept razmejiti med nevojaško in vojaško naravo tega tveganja ter za oba primera opredeliti usmeritve za delovanje. V prvem primeru bi bila vloga zavezništva praviloma osredotočena na posvetovanja, strokovno podporo in v izjemnih primerih na vojaško podporo ustreznim inštitucijam (policija, tožilstvo, sodišča, varnostne službe idr.), v drugem pa na izvajanje ukrepov za preprečevanje ogrožanja, zoperstavljanje ogrožanju z vojaškimi zmogljivostmi ter podporo pri obnovi.

Okoljska tveganja sodijo med nevojaška tveganja. Strateški koncept jih navaja kot tveganja, ki bodo določala strateško okolje zavezništva v prihodnje in vplivala na njegovo delovanje, ne ponuja pa nobenih usmeritev za delovanje zavezništva na tem področju. Po mojem mnenju gre za področje, ki ni v domeni Nata, temveč drugih organizacij. Na podobna stališča naletimo tudi ob prebiranju literature. Na tem mestu se torej poraja vprašanje, zakaj je strateški koncept to tveganje sploh uvrstil na svoj seznam.

Strateški koncept uvaja nov, tretji steber obrambe in odvračanja pred napadi na zavezništvo, sistem za protiraketno obrambo. Ta naj bi bil izdelan v sodelovanju $\mathrm{z}$ Rusijo (dejansko je med Rusijo in Natom precej nezaupanja, kar bo otežilo njegovo vzpostavitev) ter drugimi partnerji in bi moral med drugim zagotavljati obrambo celotnega ozemlja zavezništva. Gre za sistem, ki je tehnološko in operativno zelo zahteven, zlasti če bi se njegovo upravljanje delilo tudi z nečlanicami. Pojavljajo se dvomi o smiselnosti uvajanja tovrstnih sistemov, za katere velja, da je njihova učinkovitost zelo vprašljiva, so izredno dragi in predstavljajo v času pomanjkanja 
finančnih virov težko izvedljivo naložbo (Webber, 2011; Wittmann, 2011a). Na tem mestu je treba poudariti še njihov potencialno negativen vpliv na jedrsko ravnotežje, kar lahko privede do novega jedrskega oboroževanja, o čemer bo več napisanega $\mathrm{V}$ nadaljevanju.

Koncept kriznega upravljanja Nata temelji na izvajanju aktivnosti pred krizo, med njo in po njej. Zavezništvo si pri tem prizadeva za razvoj celostnega pristopa (civilni, politični in vojaški) in bo v ta namen vzpostavilo lastne civilne strokovne zmogljivosti. Nadalje si bo prizadevalo za tesno sodelovanje z drugimi mednarodnimi akterji in organizacijami, pri čemer strateški koncept izpostavlja pomen OZN in EU. Strateškemu konceptu lahko na področju kriznega upravljanja očitamo nekatere pomanjkljivosti in nedorečenosti. Koncept je pri navajanju organizacij, s katerimi naj bi Nato sodeloval na področju kriznega upravljanja, nedosleden, vzpostavitev civilnih zmogljivosti Nata na področju kriznega upravljanja pa ima lahko tudi negativne učinke. Strateški koncept navaja le pomen sodelovanja z OZN in EU. Izpustil je vsaj Organizacijo za varnost in sodelovanje v Evropi (OVSE) ter Afriško unijo, kar je presenetljivo zlasti zaradi vse večjega pomena preprečevanja kriz ter vloge, ki jih lahko imata ti organizaciji pri tem, zlasti z zagotavljanjem mehanizmov mehke varnosti, ki jih Natu primanjkuje. Članice Nata so tudi članice OVSE, zaradi česar bi se moral Nato tesneje povezati s to organizacijo, zlasti na področju človekovih pravic, krepitve zaupanja in zgodnjega opozarjanja. Vzpostavitev civilnih zmogljivosti Nata na področju izvajanja nalog kriznega upravljanja je lahko razumljena kot nepripravljenost Nata na resnično sodelovanje z drugimi organizacijami ter podvajanje zmogljivosti, ki jih te že imajo. Tako zavezništvo po nepotrebnem dviguje stroške za vzpostavitev zmogljivosti, ki morda niso potrebne in se pri rekrutiranju civilnih strokovnjakov podaja v boj z EU, OZN idr. (Katsioulis, 2011). Nato lahko za izvajanje kriznega upravljanja ponudi pretežno vojaške in politične zmogljivosti, primanjkujejo pa mu mehanizmi zagotavljanja mehke varnosti (nevojaške zmogljivosti). Zavezništvo se pri izvajanju kriznega upravljanja ne sme vmešavati v področja delovanja drugih organizacij, temveč mora z njimi vzpostaviti enakopraven odnos in si s skupnim načrtovanjem ter izvajanjem nalog prizadevati za vzpostavitev varnega in stabilnega okolja.

Tretja temeljna naloga je krepitev mednarodne varnosti s sodelovanjem z drugimi državami in organizacijami (kooperativna varnost). Kot je bilo že rečeno, strateški koncept v delu, kjer navaja pomen sodelovanja z varnostnimi organizacijami, omenja le OZN in EU. Nato bi moral na poseben način okrepiti tudi sodelovanje z nečlanicami, ki veliko prispevajo k Natovim misijam in s katerimi si deli enake vrednote ter politično prepričanje - Avstralijo, Novo Zelandijo, Japonsko idr. Na področju jedrskega razoroževanja se Nato spoprijema z vprašanjem, kako si na eni strani zagotoviti dovolj tovrstnih zmogljivosti za izvajanje odvračanja in v izjemnih okoliščinah za delovanje proti agresorju, ne da bi te zmogljivosti pomenile oviro za hkratna prizadevanja za zmanjšanje ali celo odpravo jedrskega orožja, kar je eden izmed ciljev Nata. Velika ovira pri nadaljnjem jedrskem razoroževanju bo verjetno protiraketni sistem, ki ga predvideva aktualni strateški koncept. Koncept ne predvideva 
kompenziranja posedovanja tega sistema z zmanjšanjem jedrskega orožja. Nasprotno, pripisuje mu zelo pomembno vlogo. Posledično bo Nato tako okrepil svoj jedrski položaj in morda celo spodbudil oboroževalno tekmo na jedrskem področju, zlasti, če Rusija ne bo sodelovala pri vzpostavitvi skupnega protiraketnega sistema. To bi močno zmanjšalo kredibilnost Nata na področju razoroževanja in nadzora nad oboroževanjem. Strateški koncept tako vnaša na področje razoroževanja in omejevanja oboroževanja določeno mero negotovosti (Katsioulis, 2011).

Velika pomanjkljivost novega strateškega koncepta je nezadostna vloga, ki jo posveča posvetovanju (Wittmann, 2011b). Povečana vključenost Nata v reševanje globalnih varnostnih tveganj, ki jo napoveduje novi strateški koncept, bo temeljila na aktiviranju 4. člena Washingtonske pogodbe - posvetovanje, zaradi česar bi bilo logično pričakovati, da bi ga novi strateški koncept opredelil kot temeljno nalogo, kot je to že veljalo v prejšnjem strateškem konceptu.

Sklep Obsežne spremembe v mednarodnem varnostnem okolju, nova tveganja in nove oblike odzivanja Nata nanje so botrovali k odločitvi o prenovi njegovega strateškega koncepta. Novi koncept je bil sprejet v Lizboni, novembra 2010. Njegova analiza razkriva, da je obseg varnostnih prvin v njem večji, kot je bil kadar koli v preteklosti. To gre na eni strani pripisati širokemu razumevanju koncepta mednarodne varnosti, ki ne obsega le njene vojaške razsežnosti, temveč tudi politične, gospodarske, socialne, ekološke in druge vidike, ter na drugi strani obsežnejši vlogi, ki jo Natu pri zagotavljanju mednarodne varnosti nalaga novi strateški koncept. Ugotovimo lahko, da Nato z novim strateškim konceptom širi geografski obseg svojega delovanja, obseg nalog in varnostnih tveganj, proti katerim deluje, ter širi obseg svojih partnerstev. Postaja regionalna organizacija, ki se zaveda, da ima varnost 21. stoletja globalni značaj. Novi strateški koncept izenačuje pomen kolektivne obrambe, kriznega upravljanja in kooperativo zagotavljanje mednarodne varnosti ter redefinira značaj zavezništva. Koncept preobraža Nato v hibridno organizacijo - organizacijo vojaškopolitičnega zavezništva za izvajanje kolektivne obrambe in varnostno organizacijo.

V zvezi z novim strateškim konceptom se postavlja več vprašanj. Večina tveganj, ki jih zaznava organizacija, je nevojaškega izvora, zato se pri tem poraja dilema, kako se jim bo zavezništvo, ki ima pretežno vojaške zmogljivosti, uspešno zoperstavilo. Koncept predvideva vzpostavitev sistema za protiraketno obrambo. Pri tem se pojavljajo dvomi o smiselnosti njegovega uvajanja, saj je tehnološko in operativno zelo zahteven ter izredno drag. Poudariti je treba tudi njegov potencialno negativni vpliv na jedrsko ravnotežje in dejstvo, da ni skladen s prizadevanji koncepta za zmanjšanje oziroma odpravo jedrskega orožja. Koncept je nedosleden pri navajanju organizacij, s katerimi naj bi Nato sodeloval na področju kriznega upravljanja, saj eksplicitno navaja le pomen sodelovanja z OZN in EU. Koncept bi moral nadalje poudariti pomen tesnejšega sodelovanje z nečlanicami organizacije, ki veliko prispevajo k Natovim misijam in s katerimi si deli enake vrednote ter politično prepričanje. Vzpostavitev civilnih zmogljivosti Nata na področju izvajanja nalog kriznega 
upravljanja lahko razumemo kot njegovo nepripravljenost na resnično sodelovanje z drugimi organizacijami (OZN, EU in OVSE) ter podvajanje njihovih zmogljivosti. Zavezništvo se ne sme vmešavati v področja delovanja drugih organizacij, temveč mora z njimi vzpostaviti enakopraven odnos. Kot zadnjo pomanjkljivost koncepta izpostavljam nezadostno vlogo, ki jo novi koncept namenja posvetovanju. Povečana vključenost Nata $\mathrm{v}$ reševanje globalnih varnostnih tveganj, ki jo predvideva novi koncept, zahteva ponovno umestitev posvetovanja med njegove temeljne naloge, kot je to že veljalo v prejšnjem strateškem konceptu.

1. Alcaro, Riccardo. 2010. Combining realism with vision. Options for Nato's new strategic concept. 7. maj. http://129.132.57.230/serviceengine/Files/ISN/124974/ ipublicationdocument_singledocument/3f538a84-956f-4a44-bcf4-2555891dd3a0/en/ iai1007.pdf, 26. marec 2012.

2. Flockhart, Trine. 2011. After The Strategic Concept Towards A Nato Version 3.0. Copenhagen: Danish Institute For International Studies.

3. Grizold, Anton. 2005. Slovenija v spremenjenem varnostnem okolju. Ljubljana: Fakulteta za družbene vede.

4. Grizold, Anton in Lidija, Čehulič. 2006. Međunarodna sigurnost i Nato u novom svjetskom poretku. Zagreb: Fakultet političkih znanosti.

5. Helbig, Robert. 2011. Defining its future, engaging its public: NATO's new Strategic Concept as a tool for survival. ISU Conference Paper. Hendrickson, Ryan C. Crossing the rubicon. Nato Rewiev. 2005 (1): 1-4.

6. Kamp, Karl-Heinz. 2009. The Way to Nato's New Strategic Concept. Research Paper 46: 1-8. Rim: Nato Defence College.

7. Kamp, Karl-Heinz. 2010. NATO's strategy after the Lisbon summit. http://www.atlcom.nl/ ap_archive/pdf/AP\%202010\%20nr.\%208/Kamp.pdf, 25. april 2012.

8. Katsioulis, Christos. 2011. The new Nato strategy. A Temporary compromise. Berlin: International policy analysis. http://library.fes.de/pdf-files/id/ipa/07796.pdf, 2. april 2012.

9. Kugler, L. Richard in Hans, Binnendijk. 2008. Toward a new Transatlantic Compact. Washington: National Defense University.

10. Olshausen, Klaus. 2011. NATO and its New Strategic Concept Aspirations and Limitations in a Sphere of Ambiguity. European Security And Defence 1: 12-15.

11. Ringsmose, Jens in Sten, Rynning. 2009. Come Home, Nato? The Atlantic Alliance's New Strategic Concept. Copenhagen: Danish Institute For International Studies.

12. Ringsmose, Jens in Sten, Rynning. 2011. Nato's New Strategic Concept: Comprehensive Assessment. Copenhagen: Danish Institute For International Studies.

13. Shea, Jamie. 2011. What does a New Strategic Concept do for NATO? V Nato's New Strategic Concept: Comprehensive Assessment, ur. Jens Ringsmose in Sten Rynning, 25-30. Copenhagen: Danish Institute For International Studies.

14. Strateški koncept Nata - Strategic Concept For the Defence and Security of The Members of the North Atlantic Treaty Organisation. 2010. www.nato.int/lisbon2010/strategicconcept-2010-eng.pdf, 5. februar 2012.

15. Strateški koncept zavezništva - Alliances strategic concept. 24. april 1999. http://www. nato.int/cps/en/natolive/official_texts_27433.htm,28. marec 2012.

16. Vegič, Vinko. 2005. Vloga in funkcije Nata po koncu hladne vojne. V Sodobni vojaški izzivi, ur. Anton Bebler, 181-200. Ljubljana: Fakulteta za družbene vede.

17. Webber, Mark. 2011. Three Questions for the Strategic Concept. V Nato's New Strategic Concept: Comprehensive Assessment, ur. Jens Ringsmose in Sten Rynning, 99-105. Copenhagen: Danish Institute For International Studies. 
18. Wittmann, Klaus. 2009. Towards a New Strategic Concept For Nato. Rome: NATO Defense College.

19. Wittmann, Klaus. 2011a. An Alliance for the 21st Century? Reviewing NATO's New Strategic Concept. VNato's New Strategic Concept: Comprehensive Assessment, ur. Jens Ringsmose in Sten Rynning, 31-42. Copenhagen: Danish Institute For International Studies.

20. Wittmann, Klaus. 2011b. Blueprint for the next decade. Concordian 2(3):17-23. http://www.marshallcenter.org/mcpublicweb/MCDocs/files/College/F_Publications/ perConcordium/pcv2n3eng.pdf, 11. april 2012. 